\title{
Levites, Holiness and Late Achaemenid / Early Hellenistic Literature Formation: Where does Ezra-Nehemiah fit into the Discourse?
}

\section{Introduction}

In recent studies on the question how the book Chronicles fits into the literature formation processes of the Achaemenid / early Hellenistic periods, I analysed how the Levites are portrayed with reference to the notion of holiness in different textual corpora. ${ }^{1}$ After describing the interrelationship between the Holiness legislation, the theocratic redactions in the book of Numbers, the book of Chronicles, and Ezekiel 40-48 (particularly ch. 44), I hypothesized that the following literary history played itself out in the late Persian and early Hellenistic periods:

\begin{abstract}
The Holiness legislation sparked off at least two new literature formation processes, namely two theocratic reworkings of the Priestly material in the book of Numbers, and the emergence of the book of Chronicles. Like H, Chronicles also contains a merging of Deuteronomic-deuteronomistic and Priestly notions. It relied on the "democratised" understanding of holiness in $\mathrm{H}$ when it developed the Levites' profile in terms of this concept. Chronicles prompted at least two ideological "push-backs" in which the understanding of holiness was again restricted to the Zadokite / Aaronite priests, and where the Levites were again painted in a very negative light. These two "push-backs" against the Chronicler's positive portrayal of the Levites were Numbers 16-18 (which brought the Pentateuch to a conclusion) and Ezekiel 40-48 (which brought the prophetic book Ezekiel to a conclusion). Both these final literature formation processes probably emerged in the post-chronistic era, that is, towards the end of the Persian and the beginning of the Hellenistic period. And both were rejoinders to the longstanding argument about the status of the Levites within the priesthood, and particularly whether they could also claim holiness for themselves. ${ }^{2}$
\end{abstract}

1 Louis C. Jonker, "Holiness and the Levites. Some Reflections on the Relationship between Chronicles and Pentateuchal Traditions," in Eigensinn und Entstehung der Hebräischen Bibel. Erhard Blum zum Siebzigsten Geburtstag, ed. Joachim J. Krause, Wolfgang Oswald, and Kristin Weingart (Tübingen: Mohr Siebeck, 2020), 457-74; Louis C. Jonker, "Melting Pots and Rejoinders? The Interplay among Literature Formation Processes during the Late Persian and Early Hellenistic Periods," VT 70 (2020): 42-54.

2 Jonker, "Melting Pots and Rejoinders?" 53-54.

Louis C. Jonker, Stellenbosch University 
A schematic presentation of the above-described processes could look as follows (without any claim that the diagramme is correct in scale):

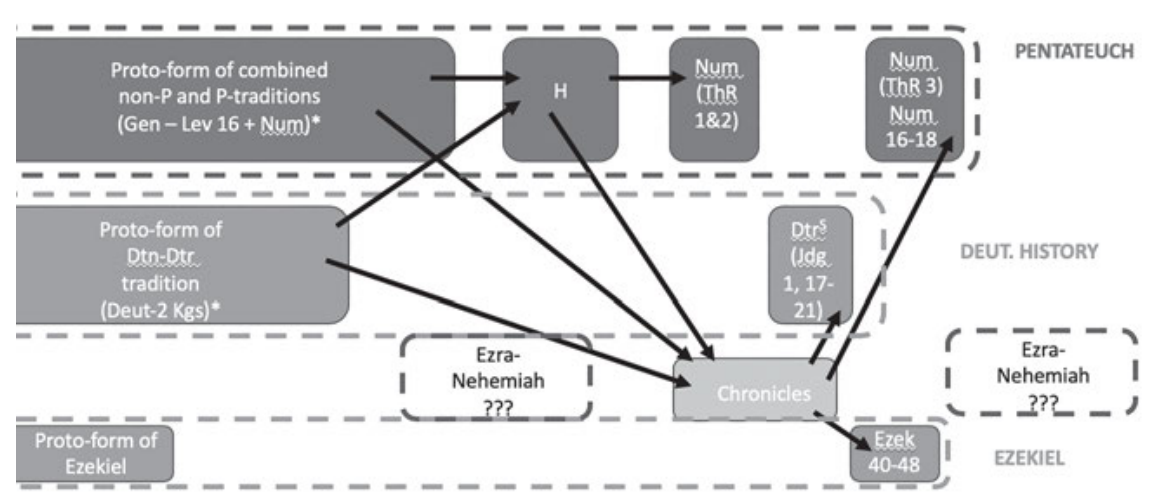

$539 \mathrm{BCE}$ 400 $-350$ 300 BCE

Figure 1: A Hypothesis on (some of) the Literary Formation Processes during the Achaemenid and Early Hellenistic Period (timeline only approximate scale)

If the above hypothesis is accepted (and my expectation is that critical testing will surely follow in scholarly publications), the question remains where Ezra-Nehemiah fits into the picture; and particularly, how does Ezra-Nehemiah contribute to the discourse on the position of the Levites, in contrast or support of Chronicles? Scholarship has come a long way since the days when Chronicles and Ezra-Nehemiah were still seen as part of the same literary work, a so-called Chronistic History. ${ }^{3}$ Nowadays, the majority view is that Chronicles and Ezra-Nehemiah are

3 Sigmund Mowinckel, Studien zu dem Buche Ezra-Nehemiah, I (Oslo: Universitetsforlaget, 1964); Sigmund Mowinckel, Studien zu dem Buche Ezra-Nehemiah, II (Oslo: Universitetsforlaget, 1964); Sigmund Mowinckel, Studien zu dem Buche Ezra-Nehemiah, III (Oslo: Universitetsforlaget, 1965); Sara Japhet, "Supposed Common Authorship of Chronicles and Ezra-Nehemiah Investigated Anew,” VT 18 (1968): 330-71; F. Charles Fensham, The Books of Ezra and Nehemiah (Grand Rapids: Eerdmans, 1982); Joseph Blenkinsopp, Ezra-Nehemiah (London: SCM Press, 1988); Tamara Cohn Eskenazi, In an Age of Prose: A Literary Approach to Ezra-Nehemiah (Atlanta: Scholars Press, 1988); Kyung-Jin Min, The Levitical Authorship of Ezra-Nehemiah, JSOT.S 409 (London: T\&T Clark, 2004); Lester L. Grabbe, Ezra-Nehemiah (London: Routledge, 2005); Lisbeth S. Fried, "Who Wrote Ezra-Nehemiah? - And Why Did They?" in Unity and Disunity in Ezra-Nehemiah: Redaction, Rhetoric, and Reader, ed. Mark J. Boda and Paul L. Redditt, Hebrew Bible Monographs 17 (Sheffield: Phoenix Press, 2008), 75-97; Paul L. Redditt, Ezra-Nehemiah, Smyth \& Helwys Bible Commentary, vol. $9 B$ (Macon: Smyth \& Helwys, 2014); Donna Laird, Negotiating Power in Ezra-Ne- 
separate works by different authors. ${ }^{4}$ Chronicles is now seen by the majority of scholars as a unity which was composed towards the middle of the fourth century BCE, most probably by an authorship ${ }^{5}$ based in the Jerusalem temple close to the Levites. However, with reference to Ezra-Nehemiah, more issues remain open for debate. ${ }^{6}$ Not everybody agrees with the tendency to see the book as one literary work; the majority now view the book as composed of different textual sources, over a fairly long period of time, even into the Hellenistic period. ${ }^{7}$ Diachronic theories about Ezra-Nehemiah will, of necessity, have an important bearing on the answering of our question as to where this book fits into the above-mentioned picture. Diachronic theories will help us to a better understanding of the literary engagements with the priestly traditions - "P" and "H" - in the time towards the end of the Persian period and the transitioning to the Hellenistic period (and even beyond). ${ }^{8}$

In the present essay, I will concentrate on the distribution of explicit references to Levites and priests in Ezra-Nehemiah, in conjunction with the occurrence

hemiah, Ancient Israel and Its Literature 26 (Atlanta: SBL Press, 2016); Bob Becking, Ezra, Nehemiah (Leuven: Peeters, 2018).

4 Japhet, "Supposed Common Authorship”; Hugh G.M. Williamson, Ezra and Nehemiah (Sheffield: JSOT Press, 1987); Thomas Willi, "Zwei Jahrzehnte Forschung an Chronik und Esra-Nehemia,” TR 67/1 (2002): 61-104; Thomas Willi, Esra: der Lehrer Israels, Biblische Gestalten 26 (Leipzig: Evangelische Verlagsanstalt, 2012).

5 I use the term "authorship" in order to avoid specifying whether it was a single hand (possible, but unlikely), or rather a collective (most likely).

6 Mark J. Boda and Paul L. Redditt, eds., Unity and Disunity in Ezra-Nehemiah: Redaction, Rhetoric, and Reader, Hebrew Bible Monographs 17 (Sheffield: Phoenix Press, 2008).

7 For a discussion on the different positions, see Juha Pakkala, Ezra the Scribe: The Development of Ezra 7-10 and Nehemiah 8, BZAW 347 (Berlin: De Gruyter, 2004).

8 My approach is thus similar (although with different conclusions regarding the time period) to Raik Heckl's when he indicates in one of his studies on Ezra-Nehemiah: "[Biblical texts] should rather be regarded as intentional literature: literature that served the aim to impart concepts of identity and to reinforce particular forms of religion. That is the reason why it was possible to work on and with these texts over a long period of time. The literary history shows that the biblical authors used their Vorlagen in different ways. Transformations, substitutions, and summarizing excerpts of older literary texts are likely as redactions and supplementations. If we accept the intentional nature of the biblical texts on different literary levels, it is possible to approach them via a discourse analytical concept. During their literary history, the biblical texts belonged to discourses about the national and religious identity of ancient Israel. Changes in the identity emerged together with - and have been enforced by - changes in the texts" (Raik Heckl, "The Composition of Ezra-Nehemiah as a Testimony for the Competition between the Temples in Jerusalem and on Mt. Gerizim in the Early Years of the Seleucid Rule over Judah," in The Bible, Qumran, and the Samaritans, ed. Magnar Kartveit and Gary N. Knoppers (Berlin: De Gruyter, 2018), 116. 
of the theme of holiness and purity. As indicated in earlier publications, ${ }^{9}$ the portrayal of the Levites in terms of holiness is quite an important element in the argument that I have thus far advanced on the literature formation processes in the late Achaemenid / early Hellenistic periods. The textual observations, mirrored against the background of some diachronic theories (such as those of Williamson and Pakkala) about the composition of the book, will help me to reach a hypothesis about Ezra-Nehemiah's position in the discourses of the same time period.

\section{Holiness and the Levites in Ezra-Nehemiah}

Our survey focuses on occurrences of terms associated with holiness (קדש), consecration (טהר), ${ }^{11}$ separation (בדל), called "language of purity" by Hannah Harrington. ${ }^{14}$ The textual data are examined with the aim of determining what relationships are reflected in them between the theme of holiness/consecration and the cultic staff, Levites and/or priests. Therefore, only those instances which are clearly related to priests and/or Levites, are included in the investigation. ${ }^{15}$ The discussion below follows the synchronic, tripartite division in the book - the diachronic aspect will get attention in $\S 3$.

9 Jonker, "Holiness and the Levites."

10 קדש appears in Ezra-Nehemiah: As verb (6 in total) - Ezra 3:5; Neh 3:1 (twice); 12:47 (twice); and 13:22; As noun (13 in total) - Ezra 2:63 || Neh 7:65 (twice in each); Ezra 8:28 (twice); 9:2, 8; Neh 9:14; 10:32, 34; 11:1, 18.

11 טהר appears in Ezra-Nehemiah: As verb (6 in total) - Ezra 6:20; Neh 12:30 (twice); 13:9, 22, 30; As noun (1 in total) - Neh 12:45; As adjective (1 in total) - Ezra 6:20.

12 appears in Ezra-Nehemiah: As verb (9 in total) - Ezra 6:21; 8:24; 9:1; 10:8, 11, 16; Neh 9:2; 10:29; 13:3. It does not occur as noun or adjective in Ezra-Nehemiah.

13 גאל II appears in Ezra-Nehemiah: As verb (3 in total) - Ezra 2:62 || Neh 7:64 and Neh 13:29. It does not occur as noun or adjective in Ezra-Nehemiah.

14 Hannah K. Harrington, "Holiness and Purity in Ezra-Nehemiah," in Unity and Disunity in Ezra-Nehemiah: Redaction, Rhetoric, and Reader, ed. Mark J. Boda and Paul L. Redditt, Hebrew Bible Monographs 17 (Sheffield: Phoenix Press, 2008), 98-116. Additional to the terms discussed here, she also investigates טמל ממא $\$$ מעל $\$ 3.2$ where I will bring more precision in our use of these terms.

15 Priests and Levites feature in the following texts: Ezra 1:5; 2:36-63; 3:8-12; 6:16-22; 7:1-5, 7, 11; 8:15-36; 9:1; 10:18; Neh 3:1; 7:39-65; 8:7, 11, 13; 10:1; 12; 13. Raik Heckl points out that the Levites occur at very specific junctures in the text: "Besonders thematisiert werden die Leviten in folgenden Zusammenhängen: 1. beim Tempelbau (Esr 3,8-10), 2. bei der Tempeleinweihung und dem anschließenden Passa (Esr 3,16-18.19f.), 3. bei Esras Rückkehr (Esr 8), 4. bei der Verlesung der Tora und ihrer Vermittlung (Neh 8), 5. bei der Einweihung der Mauer Neh 12,27 ff., und 6. bei 


\subsection{The Temple-building Account (Ezra 1-6)}

There is only one verse in Ezra 1-6 where "language of purity" is used in conjunction with priests and Levites. ${ }^{16}$ The term טהר occurs three times in connection with priests and Levites in Ezra-Nehemiah, but here only in Ezra 6:20. In this verse (where it is used twice), it is indicated that both the priests and the Levites consecrated themselves. The context in Ezra 6 is the celebration of the Passover. Very interestingly, it is emphasized here that the priests and Levites consecrated themselves כאחד ("as one”), and that כלם ("all of them”) were consecrated. The impression is thereby created that not only did both groups cleanse themselves for the celebration of the Passover (equality of groups), but they also did so in unison (unity of groups). Ezra 6 reminds very strongly of the Passover celebrations under Hezekiah and Josiah, as described in 2 Chronicles 30 and 35 where the Levites also participated in the slaughtering of the offerings after they had consecrated themselves. ${ }^{17}$

\subsection{The Ezra Material (Ezra 7-10, Neh 8)}

In Ezra 8:24 Ezra indicates (in first person speech) that he has "set apart" (בדל) twelve of the leading priests to guard the offerings for the house of God until they arrive in Jerusalem. Ezra calls these leading priests (שרי הכהנים), together with the temple vessels, "holy" (קדש) in verse 28. This clearly reflects a tradition that

der Regelung der Anteile der Leviten in Neh 13,10 ff." (Neuanfang und Kontinuität in Jerusalem: Studien zu den hermeneutischen Strategien im Esra-Nehemia-Buch, FAT 104 [Tübingen: Mohr Siebeck, 2016], 50). In our discussion, however, those instances where "language of purity" does not occur in relation to the Levites and/or the priesthood, or where the mentioned cultic personnel occur in texts without any reference to "language of purity", are not included in our survey.

16 The genealogy of Ezra 2 will be discussed under the Nehemiah Memoir where the same genealogy also occurs. The diachronic argument for this decision will be explained there.

17 See also the contribution of Esias E. Meyer in this volume. Meyer discusses the language of purity in Chronicles. The verb טהר occurs seven times in Chronicles (2 Chr 29:15, 16, 18; 30:18; 34:3, 5, 8 - all in the Hezekiah and Josiah narratives.) With reference to "holiness", I have hypothesized that those narratives in Chronicles form the climax of the development of the Levite profile in that book. See Louis C. Jonker, "Numbers and Chronicles: False Friends or Close Relatives?" HeBAI 8/2 (2019): 332-77; Louis C. Jonker, “Chronicles and Judges: Any Relationship?” in Jeremia, Deuteronomismus und Priesterschrift. Beiträge zur Literatur- und Theologiegeschichte des Alten Testaments. Festschrift für Hermann-Josef Stipp zum 65. Geburtstag, ed. Andreas Michel and Nicole K. Rüttgers, ATSAT 105 (St. Ottilien: EOS Verlag, 2019), 179-200; Jonker, “Holiness and the Levites”; Jonker, "Melting Pots and Rejoinders?" 
considers holiness as a quality that applies to the cultic environment and objects, including the priests officiating in it. However, in verses 29-30 it emerges that the Levites are also counted in - together with the priests - to transport the offerings safely to Jerusalem. Per implication, holiness therefore also applies to the Levites, and not only to the cultic objects and the priests.

As the only occurrence in the Hebrew Bible, the collocation זרע הקדש in Ezra 9:2 has drawn much attention in scholarship. ${ }^{18}$ The people of Israel, together with the priests and the Levites (9:1) are accused of not having separated themselves (לא בדל) from the peoples of the lands (מעמי הארצות), and thereby have caused the mixing of the "holy seed", which was considered to be "faithlessness" (מעמי). This accusation stands in the direct speech of an official who came to communicate the matter to Ezra. It is noteworthy that the accusation is made about the people of Israel, the priests, and the Levites in equal measure. Although the strong idea of separation from the peoples of the lands is characteristic of priestly ideology, the inclusion of all people of Israel and the Levites in the list of accused, also betrays something of the democratized understanding of holines in the Holiness legislation. ${ }^{20}$

The verb בדל is used again in Ezra 10:16, in relation to the priest Ezra. Within the context of the handling of the matter of mixed marriages, it is indicated that Ezra the Priest separated men who were heads of fathers' houses to hear the cases of those who were accused of marrying foreign wives. Although this is not strictly

18 For some recent studies on this expression, see Willa M. Johnson, The Holy Seed Has Been Defiled: The Interethnic Marriage Dilemma in Ezra 9-10 (Sheffield: Sheffield Phoenix Press, 2011); Katherine E. Southwood, "The Holy Seed: The Significance of Endogamous Boundaries and Their Transgression in Ezra 9-10," in Judah and the Judeans in the Achaemenid Period. Negotiating Identity in an International Context, ed. Oded Lipschits, Gary N. Knoppers, and Manfred Oeming (Winona Lake: Eisenbrauns, 2011), 189-224; Ehud Ben Zvi, "Re-Negotiating a Putative Utopia and the Stories of the Rejection of Foreign Wives in Ezra-Nehemiah," in Worlds That Could Not Be: Utopia in Chronicles, Ezra and Nehemiah, ed. Frauke Uhlenbruch and Steven J. Schweitzer (London: Bloomsbury Publishing, 2016), 105-28; Ntozakhe S. Cezula, "The Concept of 'the Holy Seed' as a Coping Strategy in Ezra-Nehemiah and Its Implications for South Africa,” Acta Theologica 38/1 (2018): 15-36; Pieter M. Venter, “The Dissolving of Marriages in Ezra 9-10 and Nehemiah 13 Revisited," HTS 74/4 (2018): 1-13.

19 Olyan remarks: "Lev 18:24-30 and 20:24, 26 were certainly influential on the circles responsible for the Ezra memoir, for their rhetoric of defiling alien abominations and separation from other peoples is reflected directly in Ezra 9:1, 11, 14" ("Purity Ideology in Ezra-Nehemiah as a Tool to Reconstitute the Community,” JSJ 35/1 [2004]: 7 Fn. 18.). See also Hannah K. Harrington, “The Use of Leviticus in Ezra-Nehemiah,” JHS 13 (2013): 6-9, https://journals.library.ualberta.ca/jhs/ index.php/jhs/article/view/20647.

20 For further references on this understanding of the Holiness legislation, see Esias E. Meyer, "From Cult to Community: The Two Halves of Leviticus," Verbum et Ecclesia 34/2 (2013): 1-7. 
a cultic usage of the term בדל here, it is closely related to Ezra 9:1-2 where the people of Israel, together with the priests and the Levites, were accused of not having separated themselves (לא בדל) from the peoples of the land, and that consequentially, they have mixed the holy seed (זרע הקדש). Ezra, being portrayed as "the Priest" (הכהן) here in 10:16, is the one composing the legal institutions from heads of the fathers' houses to mitigate the situation. ${ }^{21}$

\subsection{The Nehemiah Memoir (Neh 1-7; 9-13)}

The term גאל II "defile"22 (probably a late form of געל 23 occurs in connection with the priests in the parallel accounts in Ezra 2:62 and Nehemiah 7:64. ${ }^{24}$ It is indi-

21 The final text of Ezra-Nehemiah indicates an interesting shift in the portrayal of Ezra. Sometimes, like here in Ezra 10, he is prominently portrayed as "Ezra the Priest," while in other cases, for example in the role he plays in Neh 8, he rather features as the scribe teaching the people, which is a function more associated with the Levites. Pakkala (Ezra the Scribe) has seen that as one of the features that point towards the redactional history of the book. See also Reinhard G. Kratz, "Ezra - Priest and Scribe," in Scribes, Sages, and Seers: The Sage in the Eastern Mediterranean World, ed. Leo G. Perdue (Göttingen: Vandenhoeck \& Ruprecht, 2008), 163-88; Willi, Esra; Laird, Negotiating Power in Ezra-Nehemiah, 289-94.

22 Harrington describes the term as follows: “... a strong term for defilement with the sense of nausea and loathing (e. g. Lev. 26.11, 43)" ("Holiness and Purity in Ezra-Nehemiah,” 107).

23 Williamson, Ezra, Nehemiah, 27.

24 The repatriation list in Ezra 2 which is repeated in Nehemiah 7, is a diachronic enigma in biblical scholarship. Some, like Williamson, see the Nehemiah 7 version as the primary one, with the implication that Ezra 2 borrowed from the version in Nehemiah 7 (which in itself was composed of earlier lists). Blenkinsopp, however, is not at all convinced by the arguments that underlie such a position. He therefore sees the Ezra 2 version as primary, and indicates how Nehemiah 7 re-used the earlier list, and how further revisions were made there. By placing the discussion on these texts under the Nehemiah Memoir, I indicate that I find Williamson's arguments more convincing in this matter. While Ezra 1-6 is generally accepted as the latest part of the composition of Ezra-Nehemiah which tried to connect the work to Chronicles (see diachronic discussion in $\S 3$ below), it is more likely that the Ezra 2 account was taken over from the earlier account in Nehemiah 7. See Hugh G. M. Williamson, “The Composition of Ezra i-vi,” JTS 34 (1983): 1-30; Hugh G.M. Williamson, Ezra, Nehemiah, Word Biblical Commentary, Vol. 16 (Dallas: Word Books, 1985), 28-32. See also Williamson's discussion in his review of Pakkala's book: Hugh G. M. Williamson, "Review of Ezra the Scribe: The Development of Ezra 7 - 10 and Nehemia 8 (BZAW 347) by Juha Pakkala,” JTS 58/2 (2007): 587-88; Blenkinsopp, Ezra-Nehemiah, 43-44. Blenkinsopp’s position is also supported by Pakkala, Ezra the Scribe, 137-40. For further discussions on the repetition of the geneology, see Fensham, The Books of Ezra and Nehemiah, 47-49; Williamson, Ezra, Nehemiah, 24; Blenkinsopp, Ezra-Nehemiah, 83; Gordon F. Davies, Ezra and Nehemiah, Berit Olam (Gordonville: Liturgical Press, 1999), 103. 
cated that some returnees (specified in this case as descendants of priests - cf. Ezra 2:61 // Neh 7:63) could not find their names in the geneaologies of the priests, and that they were therefore excluded from the priesthood because of their defilement. The governor indicated that they could therefore not partake in the holy food מקדש הקדשים before a priest had consulted the Urim and Tummim (Ezra 2:63 // Neh 7:65). ${ }^{25}$ The reference to קדש does, however, not apply to the priest here, but rather to the holy food that was supposed to be eaten by the temple servants (from Ezra 2:58 // Neh 7:60). Although it signifies that the priest is instrumental in giving access for the people to the most holy food, it does not qualify the priest as such. ${ }^{26}$

The text in Nehemiah 10:29, where the term בדל occurs again, indicates an opposite position from the previous occurrence in Ezra 9:1-2. Here in Nehemiah 10, some have indeed separated themselves (with בדל ) from "the peoples of the lands” (מעמי הארצות). This anonymous group is mentioned alongside inter alia the priests and Levites as those parties who have entered into a curse and an oath to walk in the Torah of God (v. 30). It thus seems that the priests and Levites are not necessarily singled out as those who have separated themselves from the peoples of the lands, but that they are rather included in a bigger collective.

Two further instances of the root קדש occur in Nehemiah 11:1, 18. The pericope in verses 1-24 provides a list of all the inhabitants of the "holy city" Jerusalem. The ruling is made (by the casting of lots) that $10 \%$ of the people would live in Jerusalem, while the other $90 \%$ would have their residences in outlying towns. It seems from this text (v. 3) that those "heads of the province" were from Judah and Benjamin, and consisted of groups of priests and Levites. Even gatekeepers were allowed to live in Jerusalem, the "holy city" (as indicated in v. 19). It also emerges that some priests and Levites, together with many of the other people, remained living in the towns of their inheritance. Although the "holy city" is thus associated with the Levites and priests, this seems to be a functional arrangement, and not so

25 It is significant that the expression קדש הקדשים also occurs frequently in the Priestly and the Holiness traditions, as well as in the Deuteronomistic history. The genealogies in Neh 7 and Ezra 2 create the impression that the writer(s)/compiler(s) were probably showing allegiance with the Priestly tradition, but simultaneously opened the way towards a wider understanding of who could be involved in the temple-building - a view that reminds of the Holiness tradition's "democratizing" tendency that reflects both priestly and Deuteronomic influence.

26 Interestingly, it is the התרשתא "governor" who orders the temple servants (הנתנים) to refrain from eating the holy food until a priest has consulted the Urim and Tummim. For discussions on the "governor" and "temple servants" mentioned here, see Williamson, Ezra, Nehemiah, 27; Blenkinsopp, Ezra-Nehemiah, 92; Fensham, The Books of Ezra and Nehemiah, 56. See also Baruch A. Levine, "The Netînîm,” JBL 82 (1963): 207-12, which remains a standard reference on הנתנים 
much on account of cultic status. The fact that Levites and priests also remained living in outlying towns confirms this observation.

We have seen above that the term טהר occurs three times in connection with priests and Levites in Ezra-Nehemiah, in Ezra 6:20 (twice) and Nehemiah 12:30. Whereas the context in Ezra 6 was the Passover celebrations, in Nehemiah 12 it is the dedication of the wall. According to Nehemiah 12:30 both the priests and Levites took part in this occasion, after having consecrated themselves. In addition, it is explicated that they not only have consecrated the people, but also the wall and the gates. Eskenazi has indicated that this information "demonstrates that they (the laity) are brought into the same ritual status as priests and Levites. They become holy people. This amplifies the point made by the Israelite pedigrees: the sanctity of the people, not merely of clergy, matters." 27 Although the consecration of the wall and gates sounds more like a priestly understanding of a holy sphere, ${ }^{28}$ the consecration of Levites and the people, together with the priests, rather reflects the theology of the Holiness legislation.

קדש also occurs twice in connection with Levites and priests in Nehemiah 12:47. The pericope in verses 44-47 deals with the portions that were required for the priests and Levites in Jerusalem. These were provided from the rural lands, because "Judah rejoiced over the priests and Levites who ministered" (v. 44). Verse 47 constructs an interesting hierarchy in the provision of the portions: "All-Israel" (and no longer Judah alone) provided the daily portions to the singers and gatekeepers, and they (presumably still All-Israel, on account of the next participle active) declared the daily portions holy to the Levites, who in turn declared holy the portions to the sons of Aaron (the priests). Due to the repetition of "Levites" in the phrase, it is clear that the actors were the Levites in the last instance. All this happened "in the days of Zerubbabel and in the days of Nehemiah", with no indication of "the days of Ezra."

Nehemiah 13 reports Nehemiah's further reform measures. In verse 22 it is mentioned that he called upon the Levites (without mentioning of the priests) to consecrate themselves (with טהר) in order to guard at the gates to keep the Sabbath day holy (with קדש (סדש). This command stands in the context of Nehemiah prohibiting merchants and sellers to stay overnight outside the gates on the Sabbath when the gates were closed. Thus, holiness is associated here with the Sabbath, and the Levites' consecration was necessary to perform their service in order to keep the Sabbath holy. The focus is thus specifically on the Levites in this

27 Eskenazi, In an Age of Prose, 117.

28 For a discussion of this aspect, see Williamson, Ezra, Nehemiah, 373; Blenkinsopp, Ezra-Nehemiah, 344. 
section. It is also quite interesting that Nehemiah, a layman-governor, is the one calling upon the Levites to consecrate themselves. This tendency could clearly be associated with the theology of the Holiness legislation.

In Nehemiah 13:29, where the term גאל II is used again, it is made clear that the defilement is related to the fact that a son of Jehoiada, presumably the high priest during Nehemiah's tenure, married a daughter of Sanballat the Horonite (v. 28). This was in contravention of the law from the Holiness legislation (Lev 21:13-15) which prohibited the marriage of a priest with a woman of foreign descent. Nehemiah 13:29 indicates that this deed has defiled the priesthood, as well as the covenant of the priesthood and the Levites. ${ }^{29}$ This indication is therefore an indirect blemish on the priesthood, and the authority relied upon is clearly the Holiness legislation.

At this point, however, we should call attention to the fact that there are scholars who explicitly point out that all "language of purity" terminology in Ezra-Nehemiah cannot be treated on the same level. Jonathan Klawans (supported by Christine Hayes) has made the distinction between "ritual" and "moral" impurity. ${ }^{30}$ In their analyses of Ezra-Nehemiah, Klawans and Hayes come to similar conclusions that it is only "moral" impurity that plays a role in this book's alien polemics, and that "ritual" impurity is not at stake here. Saul Olyan, ${ }^{31}$ in response to the above views, indicate that "[t]hough Klawans and Hayes are correct to suggest an important role for the 'moral' impurity tradition in the shaping of Ezra-Nehemi-

29 There is an interesting link in this verse with Mal 2:4-8 where a covenant with Levitical priests is also mentioned (in line with Deut 33:9). This remains a task for another day, but the connection between Ezra-Nehemiah and Malachi, as part of the discourse on Leviticism in the late Achaemenid and/or early Hellenistic periods, could provide an even wider understanding of the issue being investigated in this essay. Some scholars think, however, that the mentioning of the Levites is an addition in Neh 13:29. See e. g. Blenkinsopp, Ezra-Nehemiah, 362.

30 Christine Elizabeth Hayes, Gentile Impurities and Jewish Identities: Intermarriage and Conversion from the Bible to the Talmud (Oxford: Oxford University Press, 2002); Jonathan Klawans, Impurity and Sin in Ancient Judaism (Oxford: Oxford University Press, 2004); Jonathan Klawans, Purity, Sacrifice, and the Temple: Symbolism and Supersessionism in the Study of Ancient Judaism (Oxford: Oxford University Press, 2006).

31 Although Saul Olyan also indicates that purity terminology in Ezra-Nehemiah should be correlated to the diachronic development of the book - and should therefore not merely be studied on a synchronic level - he still departs from the traditional position of dating the book according to the tenures of Nehemiah and Ezra. He sees the "Nehemiah Memoir" as the oldest part of the book since Nehemiah preceded Ezra in tenure. Although Olyan's inclination to combine synchronic and diachronic perspectives should be appreciated, his portrayal of the redactional history is no longer the accepted position in light of newer scholarship. See Olyan, "Purity Ideology in Ezra-Nehemiah," 12-16. 
ah's purity ideology, they nonetheless overstate their respective cases." ${ }^{32}$ Olyan therefore concludes that "the circles responsible for Ezra-Nehemiah drew upon, combined, and transformed notions from both purity traditions in order to shape their novel polemic against aliens and intermarriage."33

Hannah Harrington, in her investigation of the relationship between Leviticus and Ezra-Nehemiah (in its final form), not only confirms the priority of Leviticus, but also concludes that "the cultic traditions discussed above derive from both the 'P' and ' $\mathrm{H}$ ' sections of Leviticus and they are not de novo regulations in Ezra-Nehemiah ..."34

Benedikt Rausche also engages in this discussion when he indicates that although cultic vocabulary is at first glance not so prevalent in Ezra-Nehemiah "a closer look shows that this language is of structural importance for the narrative." ${ }^{35}$ After his investigation of the book, in particular the purity language in relation to the temple-building narrative, he comes to the following conclusion:

Ezra-Nehemiah does not represent a totally unified system of purity. But the idea of an expansion of holiness beyond the sanctuary, to the people as well as to the city of Jerusalem in general, is the base upon which different notions of purity depend. ... The question of purity and impurity, exclusion and inclusion, is always related to the holiness of the temple. Purity ideologies remain crucial for the definition of postexilic community according to Ezra-Nehemiah, in so far as they regulate legitimate access to the center of identity. ${ }^{36}$

Particularly Rausche's perspective is valuable for our endeavour, namely to see whether we can detect influence from the Holiness tradition in Ezra-Nehemiah as well - a tradition which we have argued earlier ${ }^{37}$ had played a significant role in the very positive portrayal of the Levites towards the end of the book of Chronicles. Although Chronicles also shows strong influence from the Priestly tradition that worked with a stricter understanding of purity and the role (and priority) of

32 Olyan, "Purity Ideology in Ezra-Nehemiah,” 15.

33 Olyan, "Purity Ideology in Ezra-Nehemiah," 16 (his emphasis).

34 Harrington, "The Use of Leviticus in Ezra-Nehemiah," 19. This shows some development in Harrington's argument. In her earlier publication she did mention that holiness is extended in Ezra and Nehemiah to the profane sphere, but stood more on the side of those seeing a coherent use of "language of purity" in Ezra-Nehemiah. See Harrington, "Holiness and Purity in Ezra-Nehemiah."

35 Benedikt Rausche, "The Relevance of Purity in Second Temple Judaism According to Ezra-Nehemiah," in Purity and the Forming of Religious Traditions in the Ancient Mediterranean World and Ancient Judaism, ed. Christian Frevel and Christophe Nihan (Leiden: Brill, 2013), 458.

36 Rausche, "The Relevance of Purity," 472-74.

37 Jonker, "Melting Pots and Rejoinders?" 
the (Zadokite) priesthood - particularly in the earlier parts of the book - there are clear signs that the Chronicler took his cue from the Holiness tradition to merge the Deuteronomic and Priestly traditions, and to redefine the role of the Levites within a broader understanding of holiness.

The challenge is now to correlate the terminological distribution in Ezra-Nehemiah (synchronic aspect - discussed above) to the processes of growth (diachronic aspect - discussed in the next section) that brought about the unified book Ezra-Nehemiah.

\section{Diachronic ordering of textual material}

\subsection{The formation of Ezra-Nehemiah}

We have seen in earlier studies (briefly mentioned in the Introduction above) that there is a broad consensus that Ezra-Nehemiah grew over a period of time into its final form, most probably from sometime in the fifth century to the end of the fourth, or even the middle of the third century BCE. Some more extreme positions, such as those of Raik Heckl ${ }^{38}$ and Israel Finkelstein ${ }^{39}$ who extend the process of growth into the Hasmonean era, have not gained support in Ezra-Nehemiah scholarship yet. It therefore seems that, at this stage of our scholarship, it is more plausible to rather go along with those proposals that see the finalization of the process of growth of this book by the end of the fourth century BCE (Williamson) or middle of the third century BCE (Pakkala). For the purpose of this contribution, the date of finalization is not so important, but rather the position represented in the majority view that the book grew over a period of time that stretched from the middle of the Achaemenid period into the Hellenistic phase. This means that the book's period of growth in its early stages precedes Chronicles, in some part overlaps with the period of origin of Chronicles, and in most part postcedes Chronicles. This is in line with Williamson's view who sees Chronicles as a product of more or less the same time period. Pakkala, however, relies for the date of Chronicles on the construction of Steins who places Chronicles much later in history. ${ }^{40}$

38 Heckl, Neuanfang und Kontinuität in Jerusalem.

39 Israel Finkelstein, Hasmonean Realities behind Ezra, Nehemiah, and Chronicles: Archaeological and Historical Perspectives, Ancient Israel and Its Literature (Atlanta: SBL Press, 2018).

40 Georg Steins, Die Chronik als Kanonisches Abschlußphänomen: Studien zur Entstehung und Theologie von 1/2 Chronik, BBB 93 (Weinheim: Beltz, Athenäum, 1995). 
This latter position has not been accepted in Chronicles scholarship, though. By accepting some aspects of Pakkala's redactional model of Ezra-Nehemiah in this contribution, I do not concur with his view on the date of Chronicles, however.

Although Hugh G. M. Williamson and Juha Pakkala broadly agree on the period of growth of Ezra-Nehemiah, they do, however, differ about which parts are the earliest, and how this process of growth took place. According to Williamson, three phases can be identified, namely "(1) the writing of the various primary sources, all more or less contemporary with the events they relate; ${ }^{41}$ (2) the combination of the EM, NM, and other sources to form Ezra 7:1-Neh 11:20; 12:27-13:31 (11:21-12:26 were added separately) ${ }^{42}$ (3) the later addition of the introduction in Ezra 1-6." ${ }^{\text {"3 }}$ Apart from the first phase of primary documents from the sixth and early fifth centuries BCE, the other two phases are dated by Williamson approximately in 400 BCE and 300 BCE. ${ }^{44}$ Williamson's dating therefore spans the transition from the late Persian to the early Hellenistic phases, and also of the presumed time of origin of Chronicles.

41 For Williamson's identification of the sources used in Ezra 1-6, see Ezra, Nehemiah, xxiv. This is strictly spoken still not part of the book's development, since these sources developed independently.

42 Pertaining to stage 2, Williamson provides the following detail: "A history of composition must, therefore, start with the combination of the Ezra and Nehemiah memoirs. The same process demands, however, the inclusion of most of the rest of the material in Neh 9-12: chaps. 8-10 are a carefully constructed compilation around the theme of covenant renewal; 11:1-2 and its dependent list are clearly intended as a narrative continuation of 7:4-5; the splicing of other material into Nehemiah's account of the dedication of the wall (12:27-43) is most reasonably to be taken as part of this same editorial activity, and 12:44-13:3 is consciously placed to introduce the remainder of the NM. In fact, only 11:21-12:26 cannot be regarded as part of this major phase in the book's composition" (Ezra, Nehemiah, xxxiv.)

43 Williamson, Ezra, Nehemiah, xxxv. Stage 3 thus consisted of the bringing of certain primary source texts into a coherent narrative, a construction that departs from the assumption that the repatriation list of Ezra 2 was taken over from Nehemiah 7. Williamson's detailed arguments focusing on the composition of Ezra 1-6 shows that the author of these chapters: “... had at his disposal a number of primary sources of such a nature as could well have been preserved in an official archive, and he also knew several other relevant works which are now found in the Old Testament. There is nothing in Ezra i-vi which cannot be explained on this minimal assumption. Indeed, the consistent editorial handling of primary sources throughout these chapters precludes any intermediate stage in the composition. The author cannot be identified with the Chronicler. Rather, he may be a member of the circle which had earlier sujected the Books of Chronicles to pro-priestly redaction. If so, he probably worked within a few decades of the introduction of Hellenistic rule into Palestine with the purpose of justifying the legitimacy of the Jerusalem temple and its cult after a possible split in its priesthood, the establishment of the Samaritan community and the first moves to build a temple on Mount Gerizim" ("The Composition of Ezra i-vi," 29-30.). 44 Williamson, Ezra, Nehemiah, xxxvi. 
Pakkala sees the Ezra Material (Ezra 7-10 and Neh 8) as the oldest part of the book, with the temple-building account (Ezra 1-6) and Nehemiah Memoir (Neh 1-7; 9-13) that were added in further stages. ${ }^{45}$ Each one of these bigger textual units also went through processes of editing and accumulation (like a "snowball", to use Pakkala's term, or, because of Fortschreibung as some German-speaking scholars would call it). According to Pakkala, the earliest literary activities can be dated towards the end of the fifth century BCE, while the final editing was completed in about the middle of the third century BCE.

The main difference between Williamson and Pakkala in terms of the broad description of Ezra-Nehemiah's formation is therefore where the Nehemiah Memoir should be positioned. Williamson sees a merging of the Ezra materials and the Nehemiah Memoir at the start of the process, with the inclusion of Ezra 1-6 at a later stage, towards the end of the the fourth century BCE. Pakkala gives a primary position to the Ezra materials, with a later merging of Ezra 1-6 to form the book Ezra. Only thereafter, the Nehemiah Memoir and the book Ezra was merged by Levitical editors into a proto-form of the book, also towards the end of the fourth century BCE.

How the detail of these processes played out in these centuries, remains unclear, however. Since many different views are represented in scholarship, ${ }^{46}$ it is almost impossible to come to final conclusions about these issues at this stage. Pakkala himself admits towards the end of his study that "many uncertainties necessarily have remained, because the preserved text does not allow a precise understanding of its editorial history." 47 However, that does not mean that theories cannot be formulated and tested in interaction with other theories. While Williamson's and Pakkala's redactional theories show some convergence, the broad processes sketched above will form the basis of the diachronic view that will be taken as basis in our further investigations below. ${ }^{48}$

45 Pakkala, Ezra the Scribe; Juha Pakkala, “The Original Indipendence (sic) of the Ezra Story in Ezra 7-10 and Neh 8,” BN 129 (2006): 17-24.

46 See e.g. Blenkinsopp, Ezra-Nehemiah; Jacob L. Wright, Rebuilding Identity: The Nehemiah-Memoir and Its Earliest Readers, BZAW 348 (Berlin: Walter de Gruyter, 2004); Heckl, Neuanfang und Kontinuität in Jerusalem; Heckl, “The Composition of Ezra-Nehemiah”; Finkelstein, Hasmonean Realities; Benedikt Hensel, "Ethnic Fiction and Identity-Formation: A New Explanation for the Background of the Question of Intermarriage in Ezra-Nehemiah,” in The Bible, Qumran, and the Samaritans, ed. Magnar Kartveit and Gary N. Knoppers (Berlin: De Gruyter, 2018), 133-48; Benedikt Hensel, "On the Relationship of Judah and Samaria in Post-Exilic Times: A Farewell to the Conflict Paradigm,” JSOT 44 (2019): 19-42.

47 Pakkala, Ezra the Scribe, 292.

48 The views of Blenkinsopp and Wright are not considered here as basis for our diachronic understanding. The main difference between Williamson's and Blenkinsopp's views is that the 


\subsection{The ordering of the texts of Ezra-Nehemiah}

According to Williamson's broad three-phased development model, the texts discussed in section 2 above can be ordered diachronically in the following way: (i) None of these texts in Ezra-Nehemiah comes from the first stage of primary sources; (ii) All references identified in our study, with the exception of one or

latter sees Ezra 1-6 as the earliest part of Ezra-Nehemiah, which stands in close structural unity with the ending of Chronicles. Blenkinsopp argues against Williamson and Japhet who paved the way in scholarship for seeing Chronicles and Ezra-Nehemiah as separate works by separate authors (as discussed above). Blenkinsopp offers some rejoinders to their arguments in order to see Ezra 1-6 as continuation of Chronicles, at least in terms of the narrative framework. One of the clearest indications, according to Blenkinsopp is the structural repetition that he sees in terms of reformation and infedility, ending in Passover celebration, in the latter part of Chronicles and in Ezra 1-6: "The last part of Chronicles is ordered according to movements of renewal and reform following on periods of religious infidelity: Hezekiah after Ahaz, Josiah after Manasseh, both followed by celebration of Passover (2 Chron. 30; 35:1-19). This pattern continues into Ezra $1-6$, where the renewal of the cult concludes with the celebration of the same festival (6:19-22).... At the celebration of Hezekiah's Passover we are told that 'since the time of Solomon son of David king of Israel there had been nothing like this in Jerusalem' (2 Chron. 30:26). Of Josiah's celebration we hear that 'no Passover like it had been kept in Israel since the days of Samuel the prophet' (2 Chron. 35:18), while the author says of the feast of Tabernacles celebrated at the time of Ezra that 'from the days of Joshua son of Nun to that day the people of Israel had not done so' (Neh. 8:17). There is a progression here which is hardly accidental: the later the point in time, the further back the retrospective allusion goes. It would be difficult to find a clearer indication of unity of conception which binds together the two works into one history with its own distinctive point of view and purpose" (Blenkinsopp, Ezra-Nehemiah, 54). Blenkinsopp's views make sense from a narrative perspective, or even canonical (as he indicates in his introduction to the book), but this structure does not exclude that later writers could shape their narrative in such a format that it would link up with an earlier narrative. Furthermore, the textual evidence of 1 Esdras does also not point to the kind of unity that Blenkinsopp suggests. His arguments therefore do not convince in terms of diachrony.

With regards to Jacob Wright's views on the diachrony of Ezra-Nehemiah, his diachronic reconstruction of Ezra-Nehemiah is problematic as well. He relies heavily on his Doktorvater, Reinhard Kratz, for the Literarkritik and redaction-critical methodology that he is using, and identifies six layers in Nehemiah. His study focuses on the diachrony of the Nehemiah Memoir, but indicates that Ezra was a later attempt to write the history contained in the Nehemiah Memoir in a backward direction. His aim in his study was to let the Nehemiah Memoir speak for itself, before pointing out how this Memoir was re-read in the further development of Ezra-Nehemiah as a whole. His redaction-critical construction, as well as his indications of the relationship to Ezra, are not generally accepted in biblical scholarship (see e. g. the reviews by Fulton, Carr and Klein in Gary N. Knoppers (ed.) The Journal of Hebrew Scriptures Vol. 7 Art. 12 (2007), https://journals. library.ualberta.ca/jhs/index.php/jhs/article/view/5646, although the exegetical insights on many of the individual texts are considered valuable. 
two, should be placed in the second phase which could be dated approximately in the period 400-300 BCE; (iii) Only one text possibly belongs in the final phase around 300 BCE, namely Ezra 6:20, while the repatriation list in Ezra 2 was copied from Nehemiah 7 into this late stage of text formation (and thus also belongs to the previous stage).

If Pakkala's theory would be used, it would boil down to more or less the same picture, with some exceptions in the Nehemiah materials. Although Pakkala does not reflect on the formation of the Nehemiah Memoir in detail, ${ }^{49}$ it becomes clear from his discussion that the basic form of this Memoir started developing in the second half of the fifth century BCE, and that it must have consisted basically of Nehemiah 2-4, perhaps 5, 6,11-12. According to this view, the texts we have identified in Nehemiah 11 and 12 would belong to the earliest phase of development, sometime towards the end of the fifth century BCE. Furthermore, Pakkala postulates that the Levitical circles who were responsible for the combination of the book Ezra and the Nehemiah Memoir also edited more materials into the Nehemiah Memoir. This phase, which lasted for quite a long period, probably towards the end of the fourth century BCE (and thus coincided with the time period in which Chronicles was written) probably saw at least three Levitical editors reworking the materials. ${ }^{50}$ These editors were not only responsible for duplicating the list of returnees in Ezra 2 and Nehemiah $7,{ }^{51}$ as well as for the relocation of the material that originally stood between Ezra 8 and 9, to become the new Nehemiah 8. Also, Nehemiah 9-10 (including one of our identified texts, namely 10:29) were added in this phase as a reinterpretation of the divine will as articulated in the Pentateuch. It shows that the Pentateuch had been closed by this time for expansions, and that reinterpretation therefore continued outside the Pentateuch. The addition of Nehemiah 1, perhaps 5, and 13 (including Neh 13:22, 29 identified above) also form part of these Levitical editings. These Levitical editors were thus responsible for combining all the material into the book Ezra-Nehemiah. ${ }^{52}$ Pakkala remarks that, "[a]s for the political context of the Levitical editors,

49 Wright, Rebuilding Identity discusses that aspect in great detail.

50 The additions in this Levitical phase identified by Pakkala are: Ezra 6:18; 7:7, 13*, 24; 8:15b-20,

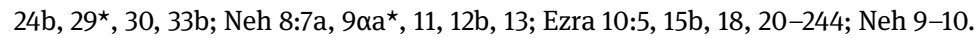

51 We have pointed out above that Pakkala (together with Blenkinsopp, but contra Williamson who sees it the other way around) holds that the Ezra version is primary. See also Wright's arguments (following Kratz) in favour of Ezra 2's priority (Rebuilding Identity, 301-7).

52 The following information provided by Pakkala is important for our quest: "It is evident that the Levitical circles disfavored Ezra and accordingly tried to diminish his role and importance. This attitude may have been caused by Ezra's prominent role as a Torah scribe, because by the time of the Levitical editors, this sphere had become their responsibility and Ezra was not a 
it is probable that the Israelite society had become more theocratic in comparison with the time of the older editorial phases."53

When the above-discussed diachronic theories are taken as point of departure, the following more detailed order can be offered:

Earliest references (from second half of $5^{\text {th }}$ century BCE) - pre-Chronistic:

\begin{tabular}{|c|c|c|c|c|}
\hline Ch & Context & Terminology & Related to & Comments \\
\hline Neh 11 & $\begin{array}{l}\text { List of inhabit- } \\
\text { ants of "holy" } \\
\text { city, Jerusalem } \\
(1-24)\end{array}$ & $\begin{array}{r}\text { בעיר הקדש } \\
(1,24)\end{array}$ & $\begin{array}{l}\text { Priests, Levites, } \\
\text { gatekeepers, } \\
\text { other people }\end{array}$ & $\begin{array}{l}\text { Reference to holiness as desig- } \\
\text { nation of the city, and not explic- } \\
\text { itly referring to people groups - } \\
\text { however, all these groups live in } \\
\text { the holy city - "democratized" } \\
\text { understanding of holiness }\end{array}$ \\
\hline \multirow[t]{2}{*}{ Neh 12} & $\begin{array}{l}\text { Dedication of } \\
\text { wall and gates } \\
(27-43)\end{array}$ & (30) טהר & $\begin{array}{l}\text { Priests, Levites, } \\
\text { people, wall, } \\
\text { gates purified }\end{array}$ & $\begin{array}{l}\text { Not only priests, but also } \\
\text { Levites, people, wall, gates } \\
\text { included in purification - } \\
\text { "democratized" understanding } \\
\text { of purification }\end{array}$ \\
\hline & $\begin{array}{l}\text { Portions } \\
\text { required for } \\
\text { priests and Lev- } \\
\text { ites (44-47) }\end{array}$ & (47) קדש & $\begin{array}{l}\text { Sons of Aaron } \\
\text { (priests) and } \\
\text { Levites }\end{array}$ & $\begin{array}{l}\text { All-Israel provided portions to } \\
\text { singers and gatekeepers, and } \\
\text { declared it holy to Levites (as } \\
\text { separate category), who in turn } \\
\text { declare it holy to the priests - } \\
\text { "democratized" understanding } \\
\text { of holiness }\end{array}$ \\
\hline
\end{tabular}

Levite. Although the Levitical expansions generally share interest in the activity of Torah scribes with the ES and Ezra's prayer, it is important to distinguish between these two phases. Whereas the authors of the ES and Ezra's prayer should be connected to the (Deutero)nomistic tradition in this respect, the Levitical editors are simultaneously interested in priestly issues. Accordingly, the older editorial stages of the EM witnesses to a scribal tradition that shows no proximity to the temple, whereas the youngest editors may represent a scribal tradition that is close to the temple circles" (Ezra the Scribe, 298).

53 Pakkala, Ezra the Scribe, 298-99. 
Later references (during the $4^{\text {th }}$ century $B C E$ ) - contemporaneous with Chronicles: ${ }^{54}$

\begin{tabular}{|c|c|c|c|c|}
\hline Ch & Context & Terminology & Related to & Comments \\
\hline \multirow[t]{2}{*}{$\begin{array}{l}\text { Neh } 7 / / \\
\text { Ezra } 2\end{array}$} & \multirow[t]{2}{*}{$\begin{array}{l}\text { List of return- } \\
\text { ees (Neh 7:5- } \\
73 / / \text { Ezra } \\
2: 1-70)\end{array}$} & $\begin{array}{r}\text { גאל } \\
\text { Neh 7:64 //) } \\
\text { (Ezra 2:62 }\end{array}$ & $\begin{array}{l}\text { Priestly descend- } \\
\text { ants }\end{array}$ & $\begin{array}{l}\text { Priestly descendants were guilty } \\
\text { of defilement of the priesthood, } \\
\text { and were therefore not found in } \\
\text { the family lists }\end{array}$ \\
\hline & & $\begin{array}{r}\text { מקדש הקדשים } \\
\text { Neh 7:65 //) } \\
\text { (Ezra 2:63 }\end{array}$ & $\begin{array}{l}\text { Holy food dis- } \\
\text { tributed through } \\
\text { facilitation of } \\
\text { priest }\end{array}$ & $\begin{array}{l}\text { Priest associated with holy food, } \\
\text { but not qualified as holy himself }\end{array}$ \\
\hline Ezra 9 & $\begin{array}{l}\text { Mixed } \\
\text { marriages } \\
(9: 1-10: 44)\end{array}$ & $\begin{array}{r}\text { לא בדל } \\
(9: 1) \\
\text { זרע }(9: 2)\end{array}$ & $\begin{array}{l}\text { People of Israel, } \\
\text { priests, Levites }\end{array}$ & $\begin{array}{l}\text { Levites and people of Israel, } \\
\text { alongside the priests, are } \\
\text { accused of not separating from } \\
\text { foreign women and thereby } \\
\text { mixing the holy seed }\end{array}$ \\
\hline \multirow[t]{2}{*}{ Ezra 8} & \multirow[t]{2}{*}{$\begin{array}{l}\text { Guarding the } \\
\text { offerings for the } \\
\text { temple before } \\
\text { arrival in Jerusa- } \\
\text { lem }(8: 24-36)\end{array}$} & (24) בדל & $\begin{array}{l}\text { Twelve of leading } \\
\text { priests (Levites } \\
\text { included accord- } \\
\text { ing to } 29-30 \text { ) }\end{array}$ & \multirow{2}{*}{$\begin{array}{l}\text { On account of vv. } 29-30 \text { it is } \\
\text { clear that Levites were counted } \\
\text { among the leading priests who } \\
\text { were separated for the task of } \\
\text { guarding the holy vessels, and } \\
\text { were therefore also considered } \\
\text { holy together with the priests - } \\
\text { "democratized" understanding } \\
\text { of holiness }\end{array}$} \\
\hline & & (28) קדש & $\begin{array}{l}\text { Leading priests } \\
\text { and temple } \\
\text { vessels (Levites } \\
\text { included accord- } \\
\text { ing to 29-30) }\end{array}$ & \\
\hline Ezra 10 & $\begin{array}{l}\text { Ezra the Priest } \\
\text { organizes the } \\
\text { mitigation of } \\
\text { the mixed mar- } \\
\text { riages }(10: 6-17)\end{array}$ & (16) בדל & $\begin{array}{l}\text { Ezra the Priest } \\
\text { functions as } \\
\text { subject, with } \\
\text { heads of fathers' } \\
\text { houses as object }\end{array}$ & $\begin{array}{l}\text { Associated with accusation in } \\
\text { Ezra 9:1-2 - countering of prob- } \\
\text { lem caused by Levites, priests } \\
\text { and lay people }\end{array}$ \\
\hline Ezra 6 & $\begin{array}{l}\text { Celebration of } \\
\text { the Passover } \\
(6: 19-22)\end{array}$ & (20) טהר & $\begin{array}{l}\text { Priests and Lev- } \\
\text { ites concecrated } \\
\text { themselves - } \\
\text { "as one" and } \\
\text { "all of them" }\end{array}$ & $\begin{array}{l}\text { Equality and unity of priests and } \\
\text { Levites emphasized - associ- } \\
\text { ation of Levites with Passover } \\
\text { (like in } 2 \text { Chr } 30,35 \text { - " democra- } \\
\text { tized" understanding of holiness }\end{array}$ \\
\hline
\end{tabular}

54 The texts are listed here in relative chronological order, according to Pakkala's views on the redaction of Ezra-Nehemiah. 
Latest references (from the end of the $4^{\text {th }}$ century to the middle of the $3^{\text {rd }}$ century BCE) - post-Chronistic:

\begin{tabular}{|c|c|c|c|c|}
\hline $\mathrm{Ch}$ & Context & Terminology & Related to & Comments \\
\hline Neh 10 & $\begin{array}{l}\text { Separation from } \\
\text { the "peoples } \\
\text { of the lands" } \\
(10: 28-39)\end{array}$ & (29) בדל & $\begin{array}{l}\text { Laity, Levites and } \\
\text { Priests }\end{array}$ & $\begin{array}{l}\text { Not only priests, but also laity } \\
\text { and Levites have separated } \\
\text { themselves - "democratized" } \\
\text { understanding of separation act }\end{array}$ \\
\hline Neh 13 & $\begin{array}{l}\text { Nehemiah's } \\
\text { reforms } \\
(13: 1-22)\end{array}$ & 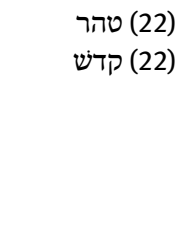 & $\begin{array}{l}\text { Levites, called by } \\
\text { the lay governor, } \\
\text { to concecrate } \\
\text { themselves to } \\
\text { keep the Sab- } \\
\text { bath holy }\end{array}$ & $\begin{array}{l}\text { Levites portrayed very positively } \\
\text { as those who are concecrated } \\
\text { to keep the Sabbath holy - } \\
\text { "democratized" understanding } \\
\text { reflected in action of lay gov- } \\
\text { ernor }\end{array}$ \\
\hline Neh 13 & $\begin{array}{l}\text { Mixed mar- } \\
\text { riages } \\
(13: 23-31)\end{array}$ & (29) גאל & $\begin{array}{l}\text { The Priesthood } \\
\text { and the Cov- } \\
\text { enant of the } \\
\text { Priesthood, and } \\
\text { the Levites }\end{array}$ & $\begin{array}{l}\text { Defilement caused by the } \\
\text { priest's son marrying a foreign } \\
\text { woman which is explicitly } \\
\text { prohibited in H (Lev } 21: 13-15) \text { - } \\
\text { priesthood and Levites thereby } \\
\text { implicated }\end{array}$ \\
\hline
\end{tabular}

With this diachronic ordering of the identified texts in mind, we can now move over to synthesize our results.

\subsection{Synthesis}

If the hypothesis that was explained in the introduction of this contribution holds truth, and when the diachronic research on Ezra-Nehemiah is considered, there should not be any doubt that the authors and compilers of the Ezra-Nehemiah literature were also exposed to the discourse on the understanding of holiness during the late Persian and early Hellenistic periods. They were exposed to the same literary and ideological milieu of the time, and we may expect some indications in the book that respond to, for example, the status of the priests and Levites in terms of a more limited (that is, cultic and priestly) understanding of holiness, or in terms of a more "democratized" understanding, which redefined the concept of holiness to apply to other priestly factions and officials, and to wider contexts than just the cultic space. The texts we have investigated indeed show engagement with this theme, with the majority reflecting a positive evaluation in terms of consecration and holiness. 
The texts in Nehemiah 11 and 12 all reveal a so-called "democratized" understanding of holiness and purification. These are not categories that are restricted to cultic personnel, places, or utensils (like in the priestly understanding), but also include Levites, gatekeepers, lay people, All-Israel, the city wall and gates.

Hannah Harrington remarks that "[w]hile in Ezra and Nehemiah there is a strong boundary between holy Israel and the rest of the world, the level of holiness between priests and laity is less distinct than in the Pentateuch" and "[t] here is an expanded sense of holy space within Ezra-Nehemiah." ${ }^{55}$ She furthermore observes that "in both Ezra and Nehemiah Levites gain more prominence than in earlier sources, ... The expansion of the holiness of the priest to the laity seems to be a trend in the Second Temple period." ${ }^{56}$ On account of these observations, Harrington shows sensitivity for the relationship between Leviticus and Ezra-Nehemiah, as well as for diachronic issues involved when she says: "Taking the position that the tolerant attitude toward the gêr in Leviticus reflects an earlier time of less crisis vis-à-vis foreigners, I beg for reconsideration of the chronology of these traditions. I call attention to elements from Leviticus which are present in Ezra-Nehemiah but are not found elsewhere in the Torah and argue for the chronological priority of these traditions over Ezra-Nehemiah." 57

We will return to this observation below in the discussion of further texts, but from the texts of this phase, and the observations above, one could agree with Harrington that understandings from Leviticus definitely played a role in the formulation of Nehemiah 11 and 12. The "democratized" understanding referred to in our comments above, but also in Harrington's observations, clearly point towards the Holiness materials (although Harrington does not make that distinction with reference to the book Leviticus). It thus seems that the Holiness legislation must have had an influence in these early discourses of the Nehemiah memoir, even before Chronicles started participating in the discourse.

\subsubsection{Later references (during the 4th century BCE) - contemporaneous with Chronicles}

In the case of the list of returnees in Nehemiah 7 // Ezra 2, various groups are differentiated, inter alia priests (Neh 7:39-42 // Ezra 2:36-39), Levites (Neh 7:43-45 // Ezra 2:40-42), temple servants (Neh 7:46-56 // Ezra 2:43-54), and

55 Harrington, "Holiness and Purity in Ezra-Nehemiah," 101-2.

56 Harrington, "Holiness and Purity in Ezra-Nehemiah," 101-2.

57 Harrington, "The Use of Leviticus in Ezra-Nehemiah," 5. 
descendants of Solomon's servants (Neh 7:57-59 // Ezra 2:55-57). However, in the section of the name list where the exclusion of some members from the returned community is narrated, a short list of people who came from specific locations (Neh 7:62 // Ezra 2:59) are mentioned alongside the priests (Neh 7:63 // Ezra 2:61). Levites are not implicated directly in this accusation of defilement, although they are part of the list mentioned earlier.

Benedikt Rausche, after studying how the term גאל functions in other biblical literature, argues that in Ezra 2:62 "a suitable translation of גיגאלו מן־הכהנה could [...] be 'they were excluded from the priesthood as inadequate'. This does not mean 'inadequate' only in technical terms. ... [T] he text takes a certain polemical tone against the discharged 'wannabe-priests' that goes beyond only technical matters." 58 This observation seems to be in line with Priestly regulations on who may act as priests. This impression is confirmed when one notices that similar terminology (מקדש הקדשים) is used in the next verse and in Numbers 18:9-10 (which I associated with a post-Chronistic theocratic/priestly "push-back" against the Chronicler's very generous treatment of the Levites). ${ }^{59}$ Rausche reminds us, however, that the Nehemiah 7 // Ezra 2 text does not see this disqualification as something permanent, and it does not apply to all the groups. Thus, what is different here in regards to Chronicles, is that the so-called "wannabe priests" are not associated with the Levites, but with some supposedly priestly descendants. The terminological link with Numbers 18 confirms that this might be part of a priestly "push-back", but the argument is not against Levites overstepping their boundaries.

Ezra 9:1-2, as we have seen above, contains an accusation against "the people of Israel, the priests, and the Levites" that they have not separated (לא בדל) themselves "from the peoples of the lands" (מעמי הארצות), and thereby have contributed to the mixing of the "holy seed" (זרע הקדשת). Juha Pakkala sees this text as part of the "prayer" expansion to the older Ezra source, around 400 BCE, in which the author probably appealed to the Torah, Deuteronomy in particular. ${ }^{60}$

Hannah Harrington also weighs in on this section, specifically on the nuances on holiness reflected here. She makes an interesting observation when she indicates that Ezra-Nehemiah's usage of the qualification of holiness is somewhat ambiguous. On the one hand, and particularly through the use of the novel collocation "holy seed" (Ezra 9:2) the book draws a much stricter border between

58 Rausche, "The Relevance of Purity," 460-61.

59 Jonker, "Melting Pots and Rejoinders?"

60 Pakkala, Ezra the Scribe, 296. 
Israel and foreigners than some Pentateuch texts. ${ }^{61}$ Harrington indicates in her discussion of the term בדל that "while the concept of separation from non-Israel is a tenet of the Pentateuch and a goal of its ritual purity system, both Ezra and Nehemiah sharpen this distinction and regard people of other races morally and ritually impure in order to reinforce an irrevocable separation between them and holy Israel. This use of separation language 'raises the bar' from earlier texts and is shared by the sources of both books." 62

As we know from Genesis 1, the term בדל is closely associated with priestly ideology, as also suggested by Harrington above. However, one of the occurrences of this term in priestly material, namely in Numbers 16:21, is quite significant for our purposes. The term is used there in the so-called Korah legend which portrays the Levites as rebellious in terms of their claim towards holiness, to indicate that these rebellious persons had to be separated from Israel. As mentioned above, I have indicated elsewhere that Numbers 16-18 might be a post-chronistic "pushback" against Levitical aspirations as expressed in, for example, Chronicles. ${ }^{63}$ Might it be that Ezra 9:1-2 latches onto this same theocratic tendency to "push back" against too liberal understandings of who should be considered to be part of the restoration community?

The texts in Ezra 8 and 10 seem to take part in the same discourse about belonging to the postexilic (cultic) community or not. In Ezra 8:24 and 28, the Levites are clearly in focus, however. They form part of those who are considered holy enough to assist with the guarding of the holy temple vessels. Here, the "democratized" tendency is again visible, where Levites occupy clear priestly functions. Ezra 10:16, on the other hand, indicates that "Ezra the Priest" tried to mitigate the problem of mixed marriages by appointing heads of fathers' houses as judges in these cases. There is no indication of Levites here, except that they were also implicated in Ezra 9:1-2 that they contributed to the mixing of the "holy seed."

Ezra 6 shows very clearly that the Levites are equal to and one with the priests, and that they were also actively involved in the Passover. This is the same "democratized" understanding that is also reflected in texts such as 2 Chronicles 30 and 35 where the Passover celebrations of Hezekiah and Josiah are mentioned, and

61 Harrington, "Holiness and Purity in Ezra-Nehemiah," 100. She also indicates that there are other biblical texts that share Ezra-Nehemiah's rejection of foreigners, such as Ezekiel 44:7-8 that labels foreigners as "uncircumcised in mind and body." Malachi 2:11-15 also falls in this category of texts supporting the position of Ezra-Nehemiah.

62 "Holiness and Purity in Ezra-Nehemiah," 115. See also Harrington, "The Use of Leviticus in Ezra-Nehemiah," 11-12.

63 See particularly Jonker, "Melting Pots and Rejoinders?" 
where the same term (טהר) is also used frequently in connection with the Levites. ${ }^{64}$ Ezra 6 surely takes the same position in the discourse on the status of the Levites than those Chronicles texts.

\subsubsection{Latest references (from the end of the 4th century to the middle of the 3rd century BCE) - post-Chronistic}

The texts mentioned above as part of the latest layer of Ezra-Nehemiah are all associated by Pakkala with Levitical editing. In two of these texts, namely Nehemiah 10:2965 and 13:22, the Levites are portrayed very positively as having separated themselves from the "peoples of the lands" and being consecrated for keeping the Sabbath holy. In the third text, Nehemiah 13:29, the verdict goes against the Levites, however. Although it is the son of a priest who married a foreign woman, the text implicates the priesthood and the Levites for this defilement. Although this is a negative assessment of the situation, the priest and Levites are however obligated in exactly the same way. Ironically, the priesthood and the Levites are on an equal footing, as 'partners in crime.' Olyan observes that - even though this text contains a negative assessment of the Levites, together with the priesthood - the text latches onto understandings coming from the Holiness legislation where the so-called "democratized" tendency is given shape in the earlier literary history of the Persian period. ${ }^{66}$

64 See again Meyer's contribution in this volume.

65 Williamson indicates with reference to Neh 10:29: "As seen above, this verse was originally the direct continuation of $\mathrm{v} 1$ and, as such, was a circumstantial clause. While a developed subject would not be impossible in such a construction, it is nevertheless probable that 'the rest of the people' once stood alone. The expansion through the remainder of the verse is to be attributed to the editor, who here shows the same concern for a comprehensive definition as he has in a different way in the list itself. There, he gathered most of the names known to him; here, he amasses every way of describing the people already found in the preceding chapters in order once more to emphasize that the agreement was undertaken by the whole community without exception" (Ezra, Nehemiah, 332). This observation reconfirms the "democratized" view expressed here.

66 Olyan, "Purity Ideology in Ezra-Nehemiah," 6-7. See also Harrington's discussion of this aspect: "The Ezra memoir and third-person narrative both consider intermarriage a sin and a profanation ... By contrast, intermarriage is allowed in Leviticus, even for ordinary priests, without any ill consequence; only the high priest must marry within his clan (Lev. 21.14). Thus, Leviticus does not ban an ordinary priest's marriage with a foreigner, and, ..., Deuteronomy provides a process of conversion; it is only Ezra-Nehemiah that regards such a union categorically impure" ("Holiness and Purity in Ezra-Nehemiah," 107). 


\subsubsection{Summary}

To summarize this section: The majority of texts in Ezra-Nehemiah where "language of purity" - particularly understandings of holiness and consecration - is mentioned in connection with Priests and Levites, reveal a "democratized" understanding in line with what we observe in the Holiness legislation. Although it is not crystal clear in all cases from where the writers / editors got their cue to portray this understanding, it seems that one can at least argue the following: (i) The texts in Nehemiah 11 and 12 - being earlier than Chronicles according to the diachronic reconstruction that we used in this contribution - most probably latched onto the Holiness material directly, shortly after the emergence of $\mathrm{H}$ as a reinterpretation of the priestly and Deuteronomic traditions. (ii) It is unclear what position vis-à-vis the Levites is represented in the duplicated list of returnees in Nehemiah 7 and Ezra 2. If Rausche is correct that the texts we discussed wanted to push back against "wannabe" priests, it could be an indication that these remarks in the list represented the same position as the (in my view, post-Chronistic) theocratic redaction in Numbers 16-18. However, in these texts - differently than in Chronicles - the theocratic "push back" is against priestly descendants and not Levites. This factor makes it very difficult to decide where Nehemiah 7 and Ezra 2 fit into the discourse, both thematically and chronologically. (iii) The texts in Ezra 8, 9 and 10 also leave us with a vague picture, although an association with the Holiness legislation can be plausibly explained. The portrayal of priests and Levites as being together (and equally guilty) in their defilement of intermarriage, points in the direction of the "democratizing" tendency that we have observed elsewhere. ${ }^{67}$ (iv) The one text which clearly shows influence of

67 Saul Olyan discusses the purity ideology in Ezra-Nehemiah as a strategy to reconstitute the post-exilic community (in response to the work of Jonathan Klawans and Christine Hayes). With reference to the exclusionist stance of this book, he indicates that two distinct strategies were used by the writers to achieve this position: first, "expansive and creative exegesis of earlier texts such as Lev 18:24-30, Deut 23:4-9, and Deut 7:1-6"; second, "the application of the concept of illegitimate profanation of a holy item to intermarriages between Judeans and foreign women" in order "to exclude those constructed as alien." This is particularly witnessed in the casting of Israel as זרע קדש "holy seed" in Ezra 9:2; and third, "a powerful and novel purity and pollution discourse explicitly informs several of the narratives that describe and justify the forced removal of persons classed as alien from temple and assembly." This novel discourse renders, according to Olyan, three results, namely "[f]irst, as in the Holiness Source, Deuteronomistic materials and other texts, alleged acts associated with aliens ... as practised by aliens themselves and the Judeans associated with them threaten the purity of the land and even Israel's continued existence ... Second, according to Neh 13:28-30, marriage with alien women pollutes the Judean priestly bloodline. And finally, Neh 13:4-9 casts the male alien as a perpetual polluter in ritual 
the "democratized" understanding of the Holiness legislation, and which clearly latches onto the Chronicler's description of Hezekiah's and Josiah's Passover celebrations, is Ezra 6:20. The text clearly supports the same position in the discourse on the Levites' status than Chronicles. ${ }^{68}$ (v) In the texts in Nehemiah 10:29 and in chapter 13 of the Nehemiah Memoir, it became clear that the positive Levitical portrayal has reached a level unprecendented compared to the earlier parts of the book Ezra-Nehemiah (probably with the exception of Ezra 6:20). One could safely argue that these texts were probably Fortschreibungen of the narrative development of the Levite profile that we witness in Chronicles. These texts are clearly post-Chronistic, and supported the same position in the discourse on the Levites than the final form of Chronicles. ${ }^{69}$

This summary shows that, as far as the diachronic reconstruction of Ezra-Nehemiah allows us, we can observe clearly that the different parts of the book engage - albeit in a variety of ways - with the more "democratized" understandings of holiness, consecration, and the Levites' position in the cult. ${ }^{70}$

terms." Olyan concludes from his discussion: "Thus, in the final form of Ezra-Nehemiah, earlier ideas of both 'ritual' and 'moral' impurity are marshaled to craft a new, complex and unprecedented ideology of alien pollution. This ideology, together with other anti-intermarriage strategies such as expansive exegesis and the application of the notion of illegitimate desacralization to Judean intermarriages, function to buttress Ezra-Nehemiah's exclusionary program" ("Purity Ideology in Ezra-Nehemiah," 2-4).

68 See also Heckl, Neuanfang und Kontinuität in Jerusalem, 392.

69 Although I agree with Pakkala that clear Levitical editorial activity can be observed in the mentioned texts, I would not go as far as Kyung-Jin Min who concluded the following: "Therefore, from our examination of the authorship issue through the available clues, we now conclude that E-N most likely came from a Levitical group who received Persian backing during the late fifth century BCE and who valued the ideologies of decentralization of power, unity and cooperation among social groups, and dissatisfaction with the religious status quo" (The Levitical Authorship of Ezra-Nehemiah, 141). Although Kyung-Jin refers to the debate on the unity of Chronicles with Ezra-Nehemiah, and of Ezra and Nehemiah, his approach is mainly synchronic, and therefore not so helpful for our present endeavour. His detection of strong Levitical interests in Ezra-Nehemiah remains valuable, however. It would therefore be worthwhile to bring Min's study into interaction with studies with a stronger diachronic interest, such as the present contribution. It would be interesting to see how synchronic and diachronic results correlate. However, this remains the task for another day.

70 Harrington observes the same when she says: "[I]t is clear that both books emphasize the notion of purification on a wider scale than found in previous texts. The purification of the laity is emphasized, at least for holy assemblies. Not only priests are in charge of purification, but also other Levites, and even, on occasion, Nehemiah, a non-Levite. ... The control of purification rites beyond priestly personnel is unique in the Second Temple period beginning with Ezra-Nehemiah. Clearly ritual purification has taken a giant step toward the centre of Israelite religion" ("Holiness and Purity in Ezra-Nehemiah,” 105-6). 


\section{Conclusion}

We have observed the following strategies in the different parts of Ezra-Nehemiah for engaging in the late Persian / early Hellenistic discourse with the issue of the status of the priesthood and the Levites, particularly with reference to holiness and consecration: (a) There is emphasis on the holiness and the consecrated status of the Levites, particularly in key events such as the dedication of the rebuilt Temple, the celebration of the Passover, and the dedication of the rebuilt wall. (b) Some texts show a clear push back against "wannabe" priests. (c) In all this, further interpretations of Pentateuchal materials, namely the Deuteronomic, Priestly, and Holiness traditions, can be observed.

Diachronically, it seems as if there are parts of Ezra-Nehemiah that latch directly onto the Holiness legislation, while others seem to engage with the "democratized" tendency in $\mathrm{H}$ via Chronicles. The youngest parts of Ezra-Nehemiah (Neh 13) clearly showed a post-Chronistic Fortschreibung.

A next step in our research would be to correlate these findings with studies on other related texts, such as Ezekiel 40-48 (particularly ch. 44), Numbers 16-18, Malachi 2, and in more depth also Chronicles. Space does not permit us to take the present attempt into that next phase, and it should remain the task of another day. 